\title{
A Phenomenological Investigation of the Presencing of Space
}

\author{
Dr. Francisco Mata ${ }^{1}$ \\ IE University, Spain \\ Email: francisco.mata@ie.edu
}

\begin{abstract}
In this paper the author explores certain fulfilling personal experiences that he describes as the presencing of space, i.e. the way in which an individual's spatial involvement may put him or her in contact with reality as a whole. These experiences are investigated from a phenomenological perspective, and the differences between them and other similar experiences, such as that of the sublime or topophilia, are highlighted. A neologism is introduced: topoaletheia (from the Greek topos, space understood as region, and aletheia, disclosure) to name a distinctive type of spatial experience. This concept may enrich the discussion about our involvement with space in our built environments.
\end{abstract}

\section{Preface}

When I think of buildings and cities, I find that most discussions in the literature leave out something that is important. On many occasions, my involvement with certain spatial realities has provided me with a sense of fulfillment or intellectual enjoyment of such a special quality that it is difficult to describe. It is on those spatial involvements that I want to focus.

I start with a few examples, my initial aim being to articulate the breadth and uniqueness of the kinds of experiences just described and their relation to phenomenological inquiry. Besides, these are not phenomena that only I have experienced. For years, I have shared comments on the sense of plenitude triggered by such spatial experiences to other people, including students and colleagues, and have realized that most of them have somehow lived similar moments. Also, one may find several similar instances described in the literature of geography, especially that of the 1970s and 80s, when there was widespread use of phenomenology in humanistic geography thanks

\footnotetext{
${ }^{1}$ The author feels most grateful to Prof. Karsten Harries for his generous supervision and most fruitful comments to this paper. Likewise, he would like to thank Prof. Andy Thornley for his constant help and support.
} 
to the works of Relph (1976), Tuan $(1974,1975,1977)$, Seamon $(1979,1982,1993)$, Seamon and Mugeraurer (1985), and Pickles (1985). ${ }^{2}$

In this essay I will follow Spiegelberg's (1960) definition of the stages of phenomenological methodology. Thus, I will firstly investigate particular phenomena and their description by intuiting and analyzing them. In this stage the focus is on identifying how the phenomena appear in one's consciousness. Descriptions of personal experiences can be readily found in the literature ${ }^{3}$ as starting points for inquiry into the essence of the object of investigation. Secondly, I will investigate their general essence through a form of eidetic intuiting. Thirdly, I will apprehend the essential relationship among essences of similar experiences, in order to understand the nuances between those experiences. Lastly, I will draw some conclusions about the understanding of those experiences.

\section{I}

Phenomenology begins in silence. Only he who has experienced genuine perplexity and frustration in the face of the phenomena when trying to find the proper description for them knows what phenomenological seeing really means. (Spiegelberg, 1960)

Describing the kind of fulfilling experiences of space that I aim to analyze has never been an easy task. I have certainly had such experiences since I was a very young boy. And yet, all my life I have struggled to put them into words; words that somehow always managed to escape the point that, ultimately, seemed to hold the key. Probably words have always failed me because they can only establish correspondences within the limited realm of previously established concepts or words, and the experiences I aim to describe seem to refuse that measure. However, when I experienced them, I was certain of their distinctive character.

What is more, as happened to the fictional Lord Chandos ${ }^{4}$ in Hofmannsthal's "Letter", the moment I attempt to give a few examples of these phenomena, they strike me as supremely foolish. But without examples I cannot hope to understand and be understood.

\footnotetext{
${ }^{2}$ For an in-depth explanation of the formulation of humanistic geography, and its commitment to the multi-dimensional nature of the lived-world, see Seamon and Lundberg (2015). Understanding the meaning of space and place for individuals has always been at the core of phenomenological inquiries carried out by humanistic geographers.

${ }^{3}$ Descriptions of personal experiences can be found in the literature as starting points of inquiry into the essence object of investigation. See, for instance, Kim (2002) on the experience of nostalgia; Adnams (2002) on the experience of singing together in mass, and $\mathrm{Wu}$ (2002) on being a foreigner. Also, Relph (1976) and Tuan (1974) are identify essences from personal experiences. ${ }^{4}$ The Letter of Lord Chandos is a fictional letter written by Hugo von Hofmannsthal in 1902 about a writer named Lord Philip Chandos who is experiencing a crisis of language. Having achieved great literary accomplishments in the past, Lord Chandos had recently lost his ability to express himself adequately after he experienced a series of epiphanies and moments of transcendence triggered by everyday life events. He made efforts to fight the deterioration of his writing skills, and thus he returned to the classics, but he found them of little help. Soon the epiphanies were lost in his inability to express them, and his life turned stagnant and grey, as his self-confidence and creativity were gone (see Hofmannsthal, 2008).
} 
I remember when, being a little boy, no more than five or six years old, my father took me to the soccer stadium for the first time to attend an important match. When we went through the tunnel and accessed the bleachers, I suddenly saw the great volume of space contained in the stadium, much bigger than any other space I had so far entered. And not only its size overwhelmed me: it was filled with strong lights (it was at night) and with the loud roar of nearly ninety thousand people singing the same tune as if they were one. All of a sudden, I felt I was no longer confined to my body, but had somehow expanded to the limits of the stadium and merged with it in a moving experience that I still remember to this day.

I remember another time, when as teenagers and unable to find any vacancy in camping sites, my friends and I were forced to sleep through the night out on a remote wide, empty beach. That night, unable to fall asleep since I could not find comfort on the sand, I looked up to the sky, and saw an enormous number of stars. I never had seen so many. That beach was so remote and devoid of any human interference that the stars managed to literally light it up. Also, I witnessed the wonderful spectacle of shooting stars: dozens of them-hundreds I would say-filled the infinite sky that night. The sea breeze on my face and the distant roaring of the waves transported me to all the remote limits of that wide beach - and I felt at home, secure, confident, full of energy. Those thousands of stars that I could see were obviously very far away, and yet I felt no distance. Something inside me leapt to the stars, and that giant elevation, combined with the feeling of being in unison with the whole extension of the beach, made me weep in joy. I transcended my limited world and found myself floating in a space that, despite being almost infinite, was so near to meeven nearer than my friends, who were sleeping just a few meters away. I have never felt more fulfilled than that night.

$\mathrm{Yi}-\mathrm{Fu}$ Tuan describes what seems to me a rather similar experience when he visited the Death Valley for the first time and was forced to sleep out in the open:

When I woke up, the sun had risen high enough to throw its rays on the range of mountains across the valley and presented me with a scene, totally alien to my experience up to that time, of such unearthly beauty that I felt transported to a supernatural realm and yet, paradoxically, also at home, as though I had returned after a long absence. (Tuan, 1974, p. xi)

One may also experience similar phenomena in more prosaic landscapes, even those that may seem most unlikely, such as in a large metropolis. To give a personal example, during my first visit to the United States, when I was 16, I went to Los Angeles, and the few days I spent there provided me with this elusive experience of plenitude. Although I never actually managed to see the ocean, the shoreline was continuously present in my intuition, somehow enclosing the vast volume of space I was witnessing. The view of the mountains on one side and my sense of the ocean on the other-with the massive city spread out in between - provided me with a sense of joy as I felt something inside me was growing. I became aware of that vast volume of space, so full of life, full of activity around me.

Architect Le Corbusier describes a somewhat similar experience that he had when he was first confronted with what it was a new phenomenon for him, fast traffic:

On that first of October 1924, I was assisting in a titanic rebirth of a new phenomenon: traffic. Cars, cars, fast, fast! One is seized, filled with enthusiasm, with joy... they joy of power. The simple and naïve pleasure of being in the midst of power, of strength. One 
participates in it, one takes part in the society that is just dawning. One has confidence in this new society: it will find a magnificent expression of its power. One believes in it. (Le Corbusier, as quoted in Dear 2000)

The same enthusiasm at being flooded with energy that Le Corbusier describes is what I felt in that trip to Los Angeles, and have subsequently felt when visiting bustling cities in exotic environments. Nevertheless, in his experience there is something missing that I believe might be important: either spatial points of reference or boundaries that may help us become aware of the space contained between them and ourselves.

Retrospectively, I can now say that it was not only the view of natural landmarks that triggered the experience; the skyscrapers of the downtown area also provided me with what Norberg-Schulz (1979) would call anchors of reference. They provided me with a sensation as if my mind was extended up to them, hence heightening my awareness of the whole volume of space. However, the expression "mind being extended" may be misleading. I was not drawn to those natural or man-made landmarks as to objects standing over against a subject; what I experienced was rather a sense of being at one with the volume of space in between those landmarks and myself. That large volume of space seemed to both separate me from and join me to those landmarks: this space was as if, in its size and fullness, it was enveloping subject and object in unison.

Apart from the mountains, the oceanfront and the downtown, many other places made me embrace that volume of space: symbolic anchors of reference, i.e. places that reminded me of Hollywood movies which I was so used to watching. Not only specific places, such as the Beverly Hills Town Hall did that, but also ubiquitous things such as those typical tall palm trees that seemed so exotic to me at that time. One object in particular triggered in me the elusive phenomenon I aim to analyze: the Hollywood sign. My first sight of what I had watched innumerable times on TV gave me goose bumps, and no matter where I went, its location remained very much alive in my intuition - together with that of the downtown, the mountains and the ocean. Being aware of all those places in between the entire volume of space structured my awareness of the whole space and gave me the sense of fulfillment that I mean to analyze here.

Interestingly, I have heard many accounts by my students and other people about similar experiences they had whenever they visited other landmarks for the first time, regardless of their function, beauty or age (e.g. the Eiffel Tower, the Giza Pyramids, the Taj Mahal, the stadium of their favourite sports team, Disneyland, etc.). It seems that one's relation to them-i.e. how present they had been in one's life up to that moment-is more important than their inherent characteristics.

I could provide several other examples of similar experiences but, as Spiegelberg (1960) points out, it is more important to find the appropriate genus or class for the phenomenon ${ }^{5}$ and describe what it is about. The phenomenon we are dealing with is one of fulfillment, something deeply moving when it is experienced to its fullest - as in the case of the beach under the starssuggesting it may be a phenomenon that has a range of intensities. While having these experiences, one may feel a sense of plenitude, an elevated joy, and feel in harmony with the world, whose

\footnotetext{
${ }^{5}$ Spiegelberg (1960, p. 672): "When we want to describe new phenomena or new aspects of old phenomena, we can do little more than assign them places within the wider framework of classes with whose other members they show at least some similarity or structural resemblance."
} 
totality seems able to embrace one's singularity. ${ }^{6}$ This may be what Hofmannsthal's Lord Chandos felt when his mind was absorbed by the sweet and foaming nourishments of his milk and his book, and felt that his life was expanding in all directions: "Everywhere I was in the centre of it, never suspecting mere appearance."

It is difficult to express these and many other similar experiences, let alone define them. In my own struggle to name them during my youth, I initially adopted the term horizontality, unaware of the use Bollnow (1961, 1971) and Jager (1971) had made of it. There seem to be a few commonalities between all the examples given above and the phenomenon of what we may call horizontality for now. In all examples, the spatial situation heightens awareness. This occurred as a consequence of the contrast these spatial situations presented with the everyday experiences of space. As Heidegger would put, once we are thrown out of the ordinary, we see more clearly, and indeed those dislocations give a sense of existing more fully. We seem to be expanding to embrace a massive volume of space, and yet we may also feel at home, joyful. This suggests that our experience of space is personal. In these moments, one's personal experience of space is clearly different from Cartesian space, and its impersonal equidistance between units of measure. ${ }^{7}$

The other aspect of this point is that such a dislocation can be triggered by a spatial reality - be it a natural or man-made landmark, by a structure's interior or even the stars. Indeed it seems that almost anything could trigger them. The exalting and moving character of the experience does not come from the intrinsic properties of the situations per se, but rather from one's relation to one's spatial reality. Thus, the literal material value of some world famous landmarks (such as the case of the Hollywood sign I mentioned above) may not be much, whereas the value of the experience they trigger may be vast. In other words, the meaning those places may have for the individual discovering them seems to be more important than their intrinsic characteristics — or their socially accepted meaning, for that matter.

Moreover, there seems a relation between the phenomena in question here and the experience of light. It seems that the larger the volume of space one can embrace and the brighter the light that fills it up, the easier it may be to experience the exaltation I am discussing. However, light here is relative to expectation, not measurable in absolute terms. In fact, some of the most moving phenomena, such as the night on the beach I described above, can only occur in relative darkness, at night.

Perhaps there are actually two metaphorical directions in which we may become enveloped by space: horizontally and synchronically, in "space" itself, what I previously called horizontality; but also diachronically, through time, resulting in a sort of tension between the two.

6 This relates to the experience of "flow" popularized by Csikszentmihalyi (1992), which he describes as those times where action and awareness merge. This occurs when music moves us, or when reading books whose stories involve us so much that we get lost and time passes with us being aware of it (Adnams, 2002). The experiences I have described seem to fall into this class.

${ }^{7}$ Bollnow's (1961) concept of lived-space seems related to the phenomena we are addressing, as they both refer to an intuitive experience of space that causes an emotional response. Nevertheless, one might say that Bollnow utilizes the term horizontality to refer to a quality of the category of space that may be experienced equally by anyone. Conversely, I was looking for a term to describe an individual feeling of expansion - expansion of one's awareness, a plenitude produced by being exposed to certain spatial contexts. 
Consider the case of Kyoto's Golden and Silver pavilions (figures 1 and 2). The walls of the upper floors of the Golden Pavilion (Kinkaku-ji) are covered in gold leaf and shine very strikingly, making the reflection of the pavilion on the lake an astonishing view. The Silver Pavilion (Ginkaku-ji), instead, is not covered in silver foil. In fact, it is hidden behind very deep vegetation and is not easily visible.
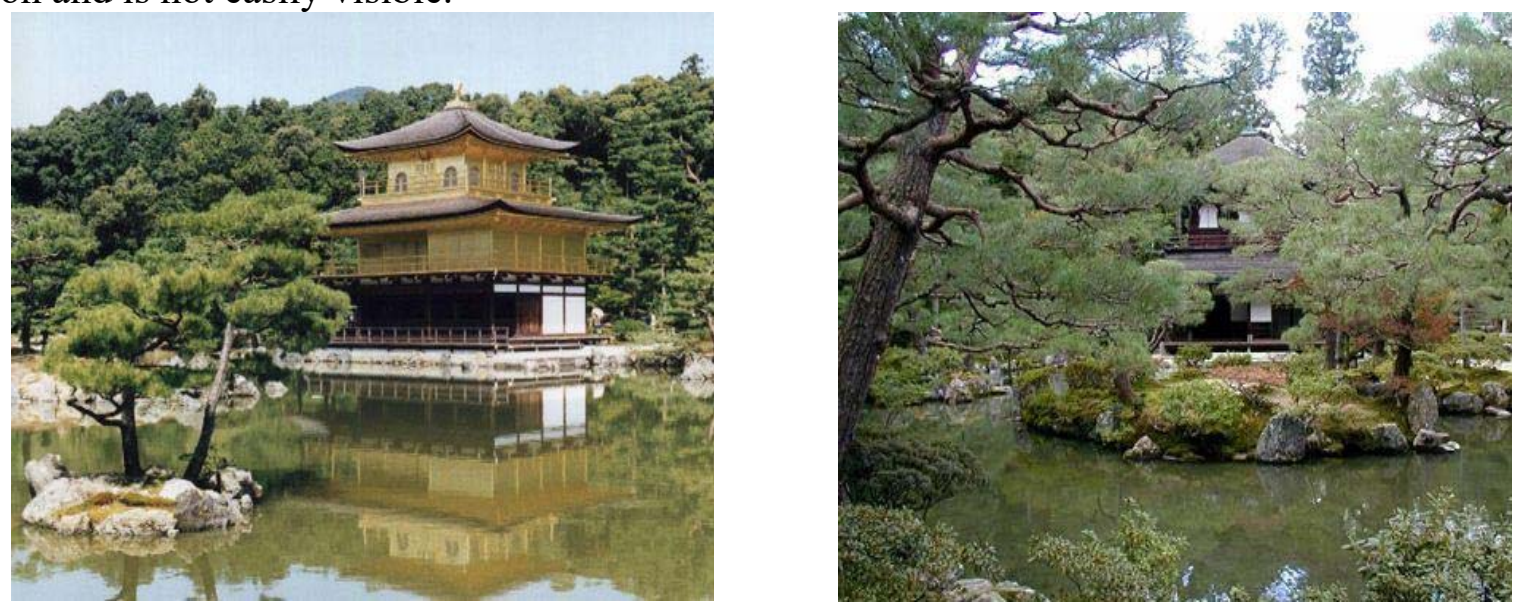

Figure 1, left: Kyoto's Golden Pavilion (Kinkaku-ji). Figure 2, right: the Silver Pavilion (Ginkaku-ji).

These two pavilions present both similarities and differences in their ability to disclose space and make us part of it. Both pavilions rest within carefully designed landscapes, crafted according to traditional Japanese gardening techniques. The Golden Pavilion is surrounded by a garden suitable for strolling, and the Silver Pavilion has a rock (Zen) garden next to it. These gardens are all significant in traditional Japanese architecture; in fact, the building is less important than the landscape that surrounds it or the views that the combination of building and park can provide.

The experience of these enclaves is likely to unfold in terms of horizontality, as one becomes part of the landscape with the help of the figures that are scattered across the garden: from the temple, which becomes just another element of the landscape, to the lake, to the carefully pruned tree to the last stone of the rock garden, which breaks the waves of gravel. If the awareness of the in-between is a necessary condition to experience the joyful feeling of being at one with space, being able to enter these Japanese gardens, with all their elements disposed in careful balance, truly helps one achieve that feeling. The beauty of these spaces makes us feel embraced by them, making us feel them as very liveable. This is in clear contrast to the self-assertive character of Western monumental architecture, with its towers, spires, naves and pinnacles always aiming high - protruding into the sky, rather than embracing us on the earth.

But it is the differences between these two pavilions in the manner they disclose space that should be pointed out. The view of the Golden Pavilion is striking, even breathtaking. Visitors standing on the other side of the pond may easily become aware of the volume of space comprised between the conspicuous walls of the pavilion and themselves, making it easy for them to feel in unison with the whole landscape. But after the first realization of that space, however strong it may be, there are limited opportunities to expand. The pavilion is closed to visitors, hence preventing any possible disclosure of the interior space. In short, the intensity of our experience of this pavilion, the space it discloses, may diminish with time.

The Silver Pavilion, in contrast, does not show itself so rapidly, and instead seems to be trying to conceal its being. It is nothing extraordinary at first in any sense: no striking color, no 
special material, and no outstanding size. Nothing. In fact, it even seems to be unfinished. ${ }^{8}$ The building, however, roots us in the soil, from which it seems to have emerged as naturally as the vegetation that surrounds it and the moss that covers the pavilion's wooded grounds.

Having been denied the kind of quick disclosure one had in front of the Golden pavilion, the patient visitor eventually gets his reward, as the Silver pavilion discloses such important meanings in piecemeal such as the central role it occupied in the development of Japanese culture at the time of Yoshimasa (15th century). This is revealed not directly, but through interpretive signs one encounters on one's way to the pavilion. After building this pavilion, former shogun Yoshimasa spent his retirement in it, a time during which he greatly contributed to the development of what Keene (2003) dubs "the soul of Japan." He developed the art of cultivating Japanese gardens, as well as encouraged Noh Theater, as well as the arts of flower arrangement and ink painting. Most importantly, one small room of this pavilion witnessed the origin of the tea ceremony.

Learning about these important meanings of the Silver Pavilion makes one extend one's intuition by reaching out to the past (i.e. to the time those significant meanings came into existence), while being anchored in the present by means of the perception of the authenticity of the pavilion, which itself seems organically grown out of the soil together with the gardens. This can result in an extended presence - of space. It is not that the disclosing ability of this pavilion lasts longer (while one is learning about those historical meanings); or at least not only. One's intuition may be stretched out from a well-rooted present to a past that — by virtue of its meaning - is as conspicuous as the gold-leaf walls of the Golden Pavilion. This reinforces one's experience of identification with that space.

The more one finds out about the Silver Pavilion, the more one may identify with its space, especially in its symbolic side, by means of its duration. This occurs as the pavilion opens up rich meanings that have been bestowed upon it without disrupting the continuity of meanings through a reduction down to the original one, when the logos of its architecture named its being. The realization of this continuity, and the space that is disclosed in the process, is what we could call the diachronic dimensions. We used the adjective diachronic, as it implies a development through time.

In summary, we can distinguish between two kinds of expansion: horizontal, i.e. expansion through becoming aware of the space in between distant places and myself-space that both separates us from and joins us to those places; and diachronic, which means expansion by understanding the ethos of the place through the different layers of signification. ${ }^{9}$ In other words, this diachronic expansion supposes becoming aware of the duration of the meaning of a place.

In conclusion: space may present itself in both directions, hence producing a certain tension within which there is room to manoeuvre. For instance, think of the great possibilities that a new theme park may strike within us, hence dislocating us from our everyday world and making space

\footnotetext{
${ }^{8}$ This appearance of neglect is in fact rooted in the Japanese wabi-sabi worldview that, with its focus on the transience of things, represents the exact opposite of the Western ideal of great beauty as something monumental, spectacular, and enduring.

9 "A townscape is born of the relationship between man and his culture and a particular natural environment; it is a manifestation of a community's temporal and spatial conception of its existence. Trying to change the fundamental character of a townscape is thus as difficult as attempting to alter the entire climate and culture of the locality" (Ashihara, 1983, p. xi).
} 
emerge. But a new theme park will not be able to disclose itself diachronically in this way. At least it will not be able to do this, for example, an old hut that may not be conspicuous at all. An old hut will make us think in a different way, by reference to the person who lived there. The world of that person will in turn be composed of a whole range of meanings that will seem to have arisen spontaneously out of the landscape, out of the soil. In contrast, a theme park is a space of simulacra, which borrows meanings from the lives of other people, from other worlds, to create a selfcontained imagined-place, and therefore its meanings are not rooted in its soil. In any case, it seems that it is in the hands of the architect or city planner to design, alter or respect spaces that may provide us with opportunities to disclose space in either directions or both, with the subsequent fulfillment it provides.

Another implication of these reflections is that, since some of the phenomena we are considering imply more than just a form of 'horizontal' expansion, the term horizontality may not do justice to those phenomena and might in fact be misleading. We therefore need to find a new name for these fulfilling phenomena triggered by space.

\section{II}

Some parts of our description of these fulfilling experiences of space may have reminded the reader of Yi-Fu Tuan's (1974) concept of topophilia. Indeed, Tuan also focused his geographical investigations on the question of how the environment provides the individual with joy and contentment, and came up with the term topophilia, which he defined as "the affective bond between people and place or setting" (1974, p. 4). As an example: one may experience topophilia when visiting one's hometown, and being surrounded by environmental elements that remind one of very fond childhood memories.

The joyful phenomena we are addressing and topophilia present themselves together in many situations - e.g. a young child going to Disneyland for the first time. Additionally, it is very reasonable to think that places that triggered an immense joyful experience will become very dear in one's memory. However, and despite that they may overlap in numerous occasions, the phenomena we aim to analyze and topophilia present sharp contrasts.

In the first place, and crucially, the role time plays in the experiences we are describing is very different from its role in topophilia. For instance: one may experience topophilia in a certain place during all of one's life- but this is one in which time might enhance that experience. In contrast, habituation seems to work against the fulfilling phenomena we are dealing with.

Habituation caused by a prolonged exposure to a certain spatial situation seems to diminish the joyful phenomena one experiences, and ultimately leads one to indifference towards the very locale that had triggered the phenomena in the first place. Let me give an example: a beautiful starry night sky like the one described above will always be beautiful, but were we to look at it continuously in an endless night spanning days and days, our initial response may wane and we would no longer feel ourselves to be expanding, and therefore we would no longer feel such exaltation.

The rationale is that if it is precisely the contrasting character of our involvement in certain spatial situations that triggers those joyful phenomena, once those spatial situations gradually become part of our everyday life, they may lose their revelatory character. This may occur along time (i.e. prolonged exposure) as well as in space, for in case there was no contrast between the stars and the darkness of the night sky (i.e. if we were witnessing a plenum of stars in the sky), the 
lack of contrast would prevent our spatial involvement with each star, thus rendering the joyful spatial phenomena perhaps less likely. Besides, it seems that there is room for different intensities, and thus not all spatial situations trigger pleasing phenomena to the same extent. Those that provide us with more intense joyful experiences seem to last longer; it seems intensity is correlated to the time they will continue to produce a contrast to everyday life. Hence, variations of one's involvement with space seem to be necessary if one is going to experience that sense of exaltation or joy.

It seems important to point out that habituation caused by repetition has a very different effects. Repetition is used for example, in rituals or festivals as a re-enactment of the meaning of the festival. It is repetition itself that reminds us of the importance (the intensity, or the meaning) of what is being celebrated (Prat-Ferrer, 2008). Hence, repetition strengthens a kind of projection, the thinking ahead of the event to come, which is part of the extended presencing of the event. This presencing envelopes the memory of the past event, the projection of the one to come, and the perception of the one being re-enacted, stretching one's involvement with the event in what Bergson (1913) would call flow (durée). Therefore, habituation to the repetition of certain events may indeed help provide those joyful phenomena (think of anniversaries), whereas habituation due to prolonged exposure may diminish their effect. ${ }^{10}$

Furthermore, and to highlight other differences between topophilia and the phenomenon we are addressing, one could wonder whether topophilia is somehow related to beauty. We feel at home in those places with which we have affective bonds (i.e. topophilia), as well as we experience positive emotions when exposed to the beautiful. We were saying that we also feel at home being exposed to those spaces we were describing above. However, we mentioned that the meaning that a place has for us seemed to be more important than its intrinsic value in its ability to provide us with this sense of plenitude (e.g., remember the example of the Hollywood sign). Therefore, an explanation of the subtle differences between topophilia, beauty and the phenomenon we are analyzing may be helpful.

A discussion about a positive, affective bond between person and place, topophilia, is related to the traditional consideration of beauty. When we experience the beautiful, we feel drawn to the revelatory object. It attracts us, makes us care for it. In fact, Edmund Burke (1757) defines beauty as "that quality or those qualities in bodies by which they cause love, or some passion similar to it". Burke's understanding is in turn based on Plato's definition of beauty as the object of love (or eros). To define beauty as the object of eros is to understand it as the object of our deepest concern. Hence, the strong emotional connection between places and ourselves defined by topophilia means that those places are the objects of our concern. This points to a significant difference between the phenomenon we are exploring and topophilia: no relationship of concern, and certainly no affective bond, between an individual and a place is required to experience the joyful phenomenon we are analyzing. For instance, I had no relationship of concern whatsoever with Los Angeles. Rather, my experience of that phenomenon occurred with no apparent reason,

${ }^{10}$ We may remember here Alice in Wonderland, where they celebrated un-birthdays so that they could make merry all days a year bar one, which seemed to them a better idea than the usual birthday celebrations, as these only happen once a year. However, one could easily argue that habituation would render all those un-birthday celebrations almost useless, as participants would find no event to celebrate and in the end those parties would become part of their daily lives' routine. 
often triggered by places that were not of explicit interest. This phenomenon occurred as if it were a gift to $\mathrm{me}^{11}$ — a kind of presentness.

One may argue that our joyful experience per se was the beginning of a relation of concern, and that one is probably no longer indifferent to that particular locale after that experience, since one's memory of that place becomes meaningful henceforth. This being so does not reduce the experiences of horizontality to those of topophilia, mainly due to a twofold reason: on the one hand, the joyful experience may begin at first sight, before any emotional bond has been established between the location and the observer. On the other hand, the longer the time that passes after such a bond is established, the less acute will be the effect of the phenomenon that triggered the experience in the first place. One becomes habituated to the phenomenon, and this necessarily diminishes the feeling of plenitude or expansion in the sense we are exploring.

The experience of topophilia is associated with relationships of care and concern, and thus it is bound to time. "Care and concern usually place us beyond the present; we are ahead of ourselves in hope or fearful anticipation, behind ourselves in anxious reconsideration of what has happened" (Harries, 1990, p. 7). Conversely, when one experiences what we were calling horizontality (i.e. the first dimension of the phenomenon we are exploring), time stands still while one is in the presence of something: one can be said to be "presencing" space. Due to its existence outside of lived time, it is very difficult to capture the significance of this presence from our finite perspective (i.e. within time). However, it seems that one could approach presence by indirection: through the spatial elements that surround one in those situations. They allow us to hold the oneness of reality in our intuition, for one realizes how all entities share the features that make us experience presence as space in the first place (i.e. our involvement within a volume contained by spatial realities). It is as if the spatial relationships of other entities among themselves also came to the fore, allowing us to participate in them. Hence we are able to intuit still further and further relationships of concern with farther entities that in turn may disclose space up to infinity.

We have mentioned the term presence and its derivatives presencing and presentness, but the term itself is in need of further discussion. In fact, understanding the meaning of presence is crucial to the description of our spatial experiences of plenitude. Presence is the most fundamental experience of reality, and yet it is so close to our being as humans that it is extremely difficult to consciously apprehend it in its pure state. It is not easy to define this term, and Harper (1991) describes it as follows:

When I am moved by a painting or by music, by clouds passing in a clear night sky, by the soughing of pines in early spring, I feel the distance between art and nature dissolve to some degree, and I feel at ease. I then feel that there is no past and no future, and I am content. [...] It is not monism or dualism; it is a unitary experience and an experience of totality in the midst of shattering differences. (pp. 6-7)

There are a number of ways we can understand presence. It may be defined as the state of being present, meaning immediateness. Or it can also refer to a sense of transcendence, of something

11 This might bring one to recall Marion (2002), for whom "every phenomenology is a phenomenology of givenness" and calls for an "origin," something that gives what is given. This interest in the origin and hence in the property of givenness of that which is given differentiates Marion's understanding of presentness from Heidegger's, which I will discuss shortly. 
beyond to what is actually being presented to us. I hope to explain that these two understandings of the term are not at odds with each other.

Presence is characterized in the literature as implying immediateness. As Fried (1998) asserts, presence (or presentness) occurs as a kind of instantaneousness that one experiences. This refers to an instantaneousness of meaning beyond the burden of time that binds us in our everyday life. This experience may be associated with a sense of intellectual enjoyment. To cite an example from Hofmannsthal's Letter (2008, p. 76), the revelatory experience of immediateness when seeing everyday gives him a sense of

an immense sympathy, a flowing over into these creatures, or a feeling that an aura of life and death, of dream and wakefulness, had flowed for a moment into them-but whence?

He suggests that the source of this immense sympathy is the presence of the Infinite, which gives him a shudder - "running from the roots of [his] hair to the marrow of [his] heels" - that may remind the reader of some of my experiences described above.

Another possible explanation for this "immense sympathy" can be found in Kant's approach to beauty. For Kant, the beautiful is associated with a disinterested satisfaction that is, first of all, disinterested because it disrupts our relation of concern to the object we consider beautiful. Concern, or interest, is linked to desire, to will, and therefore the real existence of the object (i.e. as regarded in the "natural attitude") that triggers this interest is not itself a matter of interest. In contrast, in the beautiful we lose ourselves to the presence; we enjoy the presence without further qualms. Secondly, beauty may lead to satisfaction because this is a feeling that arises on the achievement of a purpose, or at least the recognition of a purposiveness (finality). Presence as rose, to follow the example above, is completed in itself: "A rose is a rose is a rose", as Gertrude Stein said, which reminds one both of Heraclitus' assertion that the ground of existence belongs intimately together with Being, and also of the "is-ness" (Istigkeit) of Meister Eckhart. This finality is what produces satisfaction, following the Kantian approach to beauty. The Platonic sense of beauty as an object of love or eros, however, cannot lead to satisfaction since, as mentioned earlier, loving something is making it the object of our deepest concern.

When we are concerned with something, we are bound to time and, thus, presence will slip between our fingers, rendering us unable to experience the presentness of the object of our concern, hence leaving us dissatisfied. Therefore, having strong emotional interests in a place, like the affective bonds Tuan defined as the essence of topophilia, prevents us from experiencing presentness.

However, the question of time requires further explanation in relation to the phenomena we are exploring. Fried argues that presence saves us from the burden of everyday existence, which he identifies with the burden of time. For him, presence is out of time. It implies timelessness, and makes us realize of our own finitude through the interaction of our present attention and our projections. This makes presentness endless in its duration. This endless duration is in turn understood in contrast to the actual passage of time as one stands in front of the object that presents itself. "It is this continuous and entire presentness, amounting, as it were, to the perpetual creation of itself, that one experiences as a kind of instantaneousness" (Fried, as quoted in Harries, 1989, p. 27).

If presence is outside of time, there must however be a conflict with the phenomenon we are exploring, since time does seem to matter in the experience of the diachronic dimension of a phenomenon. This diachronic side implies an understanding of the meaning of a place, and it is 
related to the meaning that has been incarnated into the spatial entities that provoke the experience. This incarnation of meaning in matter is akin to what Walter Benjamin (1968) understands as aura: an incarnation of spirit in matter so complete that there is no distance between the two. This incarnation necessarily needs time to emerge, marking a difference between the phenomenon we are exploring and presentness - including the presentness of beauty: the diachronic dimension of this phenomenon is not tied up with presence as just defined.

\section{III}

We mentioned above that with the beautiful we feel at home, as we establish affective bonds that make us experience it as if it had been made for us. The experience of the beautiful thus "places" us, and it is difficult not to become attached to it. Once we fall into the temptation of becoming attached, familiarity ends up breeding indifference. Familiarity makes even the most beautiful object lose its conspicuous character; it renders the object unable to stand out of the ground that other objects and spatial involvements embody. In short, it makes us too closely bound to the object.

Having explored the relations between the concepts of beauty and presence and the phenomena we are analyzing, one could argue that it is necessary to tackle those exalting experiences of space from the view that is opposed to topophilia. This view must signify the opposite of being bound to objects, and thus it must deal with such an unrepressed search for freedom that one exposes oneself to the unknown and even to the threatening.

We have mentioned above that one may long for bigger volumes of space to be disclosed to oneself. The bigger the volume of space we could become at one with, the more fulfilling our experience might be, and the more intense our feeling of freedom might also be. "A spacious horizon is an image of liberty," as Addison (1712) states, an expression that Harries (2001) interprets as follows:

What matters in this context is how the vast expanse observed [...] becomes a figure of an even vaster interior space. Spatial extension becomes a metaphor for the boundless extension of the spirit, which leaves behind not only every here but also every now. (p. 155)

Indeed, in my own experience, the larger the volume of space I become aware of, the more empowered I felt. The presentness of this space was so immediate to me that it is as if my spirit was being stretched out to the limits of that space-i.e. to the spacious horizon Addison mentions. Rather than making me feel liberty, or rather free, in a strict sense, these large spaces made me feel confident, full of energy.

However, this search for freedom or empowerment can be frightening. Whenever one is searching for what we used to call horizontality, and puts oneself in situations in which one may perceive larger volumes of space, one runs the risk of losing sight of the limits of such a volume, in which case one will likely feel kenophobic. ${ }^{12}$ One may have this fearful experience since one

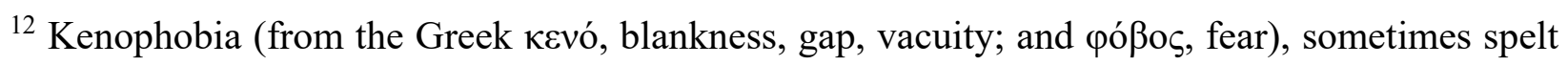
cenophobia, means the fear of open, vast, empty spaces, and it is oftentimes mistakenly associated with agoraphobia, which is most commonly described as the fear of crowded spaces. Nowadays, 
has no anchors of reference and, therefore, one is unable to become aware of any volume of space. For example, when out at sea, departing from the coastline, and heading farther and farther into the ocean, one comes to be in the midst of a vast extension of limitless water. Kenophobia is in fact the opposite of being placed - the being at home that comes with topophilia.

There is a tension between our longing for freedom and our desire to be placed; between our care for the beautiful, familiar places that surround us in everyday life and the lure but also horror that comes with exposure to the unknown. Therefore, in those joyful instances it seems one achieves a certain point of equilibrium in this tension between one's desire for freedom and the fear of reaching a state in which one might feel kenophobia.

If those joyful spatial experiences that we have described bring topophilia to mind, mentioning the threatening character of the unknown makes us think of the concept of the sublime. The Oxford Dictionary defines the sublime in nature and art as that "affecting the mind with a sense of overwhelming grandeur or irresistible power; calculated to inspire awe, deep reverence, or lofty emotion, by reason of its beauty, vastness or grandeur." So far, it seems that the phenomena we are exploring are not too far off from this description, although we already explained how beauty does not necessarily correlate to the nature of those phenomena - to their relative importance of size or grandeur (e.g. think of the Hollywood sign).

Let us now be more specific. For Burke, the sublime experience unleashes the strongest emotion in human beings, since it consists of a sort of terror and pain caused by one's exposure to the violent, uncontrollable might of Nature, which renders one weak and insignificant. He argues that the passion caused by the experience of the sublime in nature is "astonishment."

Astonishment is that state of the soul, in which all its motions are suspended, with some degree of horror. In this case the mind is so entirely filled with its object, that it cannot entertain any other. (Burke, 1757)

Burke argues that whereas the beautiful attracts our passion of love (i.e. one feels at home with or drawn to the other), in the experience of the sublime we feel homeless, defenceless. We can see this in "The Monk by the Sea," a painting by Caspar David Friedrich (1774-1840) that captures the defenceless feeling we may experience when our will is in collision with the might of Nature (see figure 3). Friedrich himself comments: "Close your eyes and your inner eye will see all the more clearly".

The main difference between the phenomena we are analyzing and the experience of the sublime, as described by Burke, does not seem difficult to grasp. For Burke, the sublime experience arouses awe and respect in the face of Nature's power and vastness. This renders one humbled; one feels frail and insignificant before the might of a world or reality that defies one's will —and yet it is this threatening aspect that is a key part of the aesthetic experience. On the contrary, the experiences we are exploring are fulfilling, for one feels in communion with the spatial situation one is experiencing. Far from horror, in these experiences we feel at one with our surroundings. We feel as if they are not separated from us, but joined with us in a continuous spatial realitysomething impossible to achieve in a scene like the one depicted in "The Monk by the Sea." It is in those situations that one feels confident, as we discussed above.

the neologism "space phobia" (also called pseudoagoraphobia) seems to be gaining popularity, and it is also used to describe the fear of big, empty spaces (see Gelder, 1982). 


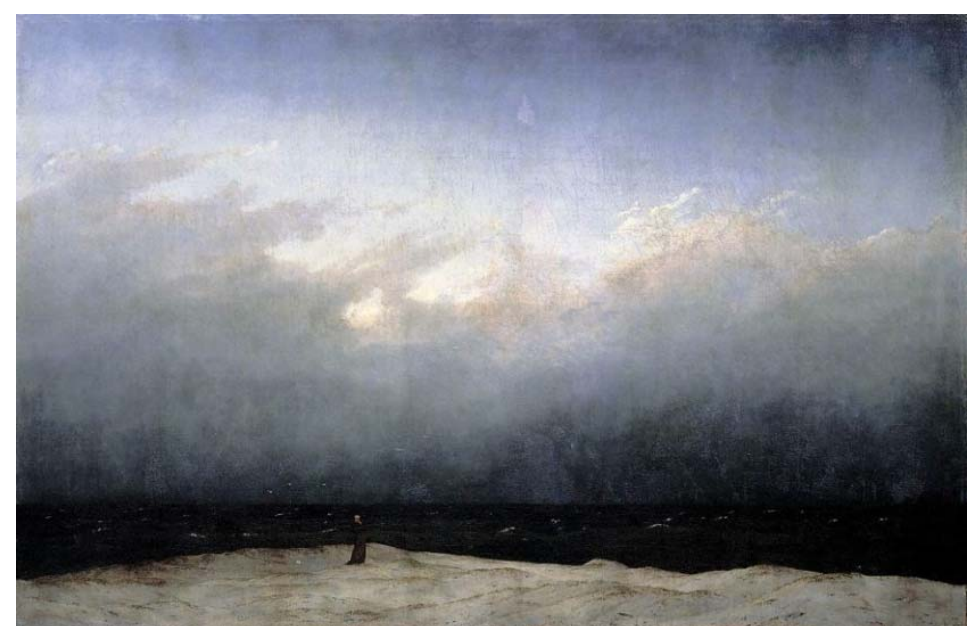

Figure 3: "The Monk by the Sea", by Caspar David Friedrich (1808-10).
Kant, however, regards the homelessness into which the sublime displaces us in a more positive way than Burke. In fact, one might say that for Kant such homelessness is even exhilarating. He looks at this homelessness as an unbounded freedom that encourages that which is most human: our reason. Kant provides us with a significant revision in one understanding of the sublime: it is our reason which becomes the object of the sublime, and not vast boundless spaces, huge mountains or fierce storms. To explain: what is properly sublime are ideas of reason, such as the ideas of absolute totality or absolute freedom. However huge the size of the sea or the mountain, they are greatly outsized by an absolute totality. However powerful the storm, it is puny compared to absolute freedom. ${ }^{13}$

One might point out that, in realizing the totality of space by means of sublime spaces, Kant is dealing with the disclosure of space, which we put at the core of the phenomenon we are addressing. In a sense, he is also expanding himself to the extent of the space of the sublime, since he is apprehending within his reason the totality of space, which is necessarily larger than the sublime space.

However, there is an important difference between the effects sublime places have upon us and the fulfilling experiences of space we are discussing: sublime places appear boundless. One of the features Burke enumerates of sublime places is that they are "apparently infinite, because of the uniformity and succession of their elements." Likewise, Kant argues that whereas beauty is connected with the form of the object which has boundaries, the sublime is to be found in a formless object, represented by a boundlessness (Critique of Judgement, §23). Conversely, one may experience the fulfilling phenomena we described at the beginning of this essay when one perceives - or intuits - the limits of a volume of space.

A limit is "what first makes a being into a being as differentiated from a non-being. Limit and end are that wherewith a being begins to be" (Heidegger, 1959, p. 60). The limit is, therefore, that from which something begins its presencing: limits make it simultaneously possible and impossible for us to feel at one - while retaining our being - with the volume of space they delimit.

Therefore, we must distinguish between the type of disclosures enabled by the sublime and those at the essence of the phenomenon that we are analyzing. Following Kant's approach to the subject, sublime places represent a disclosure of space — of the endless, unlimited or empty space

${ }^{13}$ For Kant (1790) the experience of the sublime results in the realization of the ideas of totality and reason. There are, however, several things that are experienced before one gets to that point. These initial movements of the mind-like encountering an object that cannot be comprehended by reason or imagination - do seem more related to the spatial realities associated with the joyful phenomena we are exploring. 


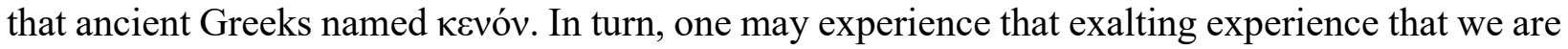
exploring when one is able to disclose the space contained within boundaries-i.e., space as $\tau$ ó $\pi$ o $\zeta$, or region.

Dwelling spaces are always finite, bounded. Space in its original meaning of 'place cleared or freed for settlement' is cleared and free...within a boundary,' a boundary being 'not where something stops but...that from which something begins its presencing.' (Heidegger, 1971, p. 154)

The experience of space as $\tau$ ó $\pi$ ऽ, or region, is to be positive and enjoyed; it allows us to dwell not only because we feel somewhat protected by virtue to its limits, but also because it is these limits that, following Heidegger, allows us to experience space as presence. In contrast, the vastness or

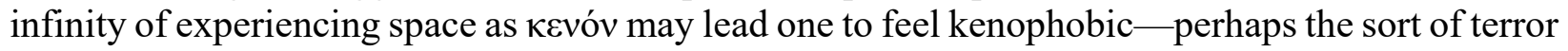
Burke described as coming with the experience of the sublime.

Let us look once more at the scene depicted in "The Monk by the Sea." The monk, one can speculate, cannot perceive the limits of the nature that he is contemplating. The vastness of the sea and heaven in front of him, enhanced by their obscurity, renders the monk free and homeless. The vast expanse observed, as was quoted above, "becomes a figure of an even vaster interior space. Spatial extension becomes a metaphor for the boundless extension of the spirit" (Harries, 2001, p. 155). But the monk is not at one with the space that surrounds him, since he cannot perceive or intuit its limits.

There is a further difference between the experience of the sublime and that of the phenomenon we aim to understand. The meanings one associates with a place can enhance or hinder this fulfilling phenomenon-e.g. the enhancing effect that the symbolic images Los Angeles had for me as a teenager. In contrast, the experience of the sublime at a given location may be more easily experienced by different individuals, as it is often the intrinsic characteristics of a place, its boundlessness, that make it sublime.

One may point out that there is a major similarity between the sublime experience and the features one may find out about the phenomenon we are studying: both suggest openness to transcendence ${ }^{14}$. For instance, in The Monk by the Sea, Friedrich is showing us a monk whose spiritual self can be interpreted to be expanding precisely due to the features of the landscape he is involved in:

In the sublimity of nature human beings recognize their own sublimity, recognize that within that allows them to transcend all that is finite and thus puts them in touch with the infinite. (Harries, 2001, p. 150)

\footnotetext{
${ }^{14}$ It is worth pointing out that we are considering the sublime here in its Romantic notion, which is the one explored in this essay as based on Addison (1712), Burke (1757), and Kant (1790), and as interpreted by Harries (2001), Weiskel (1976) and to some extent also in Newman (1948). Contemporary discussion on the sublime has taken another direction, regarding it more as an issue of immanence - see Lyotard's (1994) Lessons on the Analytic of the Sublime. Also see Freeman (1995) for a related feminist approach to the sublime, as well as Jameson (1991) for a postmodern approach.
} 
Sublime places make us realize that our lives are not the measure of all things. Likewise, in the phenomena we are exploring, one feels at one with those entities with which one establishes spatial relationships.

Similarly, the experiences we are exploring have some resemblance to the concept of the numinous, as popularized by Otto (1923) to describe the non-rational, non-sensory experience that, according to him, underlies all religion. Both experiences produce an exhilaration of noticeable quality, and lead one to experience what seems to be a communion with a "wholly Other", as Otto put it. This experience of believing that one is coming into communion with the "wholly Other" gives one a sense of transcendence very close to the experience of the sacred, understood in the way Eliade (1957) describes it when he studied the features of sacred space. One might argue that Eliade's notion of the sacred is related to the diachronic dimension of the phenomena we are studying, as sacredness irrupts into and across landscapes by virtue of the collective narratives bestowed upon them over time. This implies an involvement with the ethos of a community, which facilitates the provision of the diachronic dimension of the phenomena. Along this line, in his wonderful book The Landscapes of the Sacred, Belden Lane (2000) describes sacred space as "storied space" that requires poetic insight and analysis. Most relevant to our discussion is Lane's description of how space is transformed from a static locale into an energy field that captivates the imaginary by means of unique, significant events (kairos) that break into the temporal process (chronos). This intersection of time and space in the experience of the sacred corresponds with the intuition of those who may have experienced the phenomena we are discussing. ${ }^{15}$

The numinous, however, is an experience that is both terrifying and fascinating at the same time - one could possibly summarize it with the word "uncanny." This makes the experiences we are exploring different from those of the numinous. The phenomena we described can be associated with intellectual joy. One's awareness is heightened, and one finds oneself feeling more lucid, having a sense of existing more fully through the experience of a spatial location. This spatial experience, despite not being ordinary, is not uncanny - let alone terrifying - but one that gives one a sense of plenitude; it is a positive experience.

The concept of the numinous, however, does seem to have certain similarities with the experiences we are describing, especially due to its connotation of feeling wonder and awe. ${ }^{16}$ Wonder and awe are feelings that one may experience when exposed to certain landscapes that, due to their out-of-the-ordinary features, make one feel at a loss; making one unable to express the new sensation one may be having, exposing a sense of inadequacy, even vulnerability (Hove, 1996). Hence, resorting to religious vocabulary is a common response, because our identity seems to be challenged; we may feel the need to feel rooted again by naming what we feel.

Awe is indeed a common initial response to the dislocation of our everyday spatial relations we were discussing above. Wonder, however, is a more reflective feeling, which occurs while one tries to comprehend a new situation (see Verhoeven, 1972). Awe motivates wonder, and wonder "suspends our habitual views of things, revealing them in a 'new light', and as a

${ }^{15}$ Other interesting sources exploring the relation between the sacred and space are: Barrie (1996), Brown (2004), Jones (2000), Turner (1979) and White (1995). For more general studies on the phenomenology of the sacred and religion, see Flood (1999), Hick (1989), O'Hear (1984) and Smart (1973).

${ }^{16}$ There are numerous phenomenological investigations on the phenomena of wonder and awe and on the evocative nature of certain landscapes that seem to bring with them. See, for instance, Bonner and Friedman (2011), Elkins (2001), Elkins et al. (1988), and Parsons (1969). 
consequence, propels us into, and establishes anew, our relations with the world/other" (Hove, 1996, p. 437). Attentiveness to wonder, and to the many dimensions of experience that it reveals in our lives, can cultivate a sensitivity to the emergence of wonder in others. Thus, it has significant implications for the way in which we can be pedagogically oriented towards students ${ }^{17}$ (Hove, 1996).

However, the phenomena we are exploring are shaped by a second response: the expansion of one's awareness to the extent of the landscape we are exposed to, and hence to the fulfilling experience of plenitude. The spatial relation one establishes with the surroundings in those situations induces in many a sense of awe, and wonder. However, the emphasis is on this third movement: fulfillment.

The upshot of this discussion is that, as Jaspers (1971) points out, one acquires knowledge of one's perceived transcendence by contemplating the evanescent ciphers of transcendence, which signify the limits of human consciousness. In the case of the experiences which we are exploring, these ciphers, as Jaspers explains, can be encountered in nature, in art, in religious symbolism. They are the spatial realities (places) that function as the limits of volumes of space. Without them, no perceived expansion is possible and, in fact, one may succumb to the kind of horror associated with the sublime experiences described by Burke.

\section{Epilogue}

We need to find a term to describe the fulfilling phenomenon that is the subject of this essay. The term "horizontality" is incomplete and even misleading; topophilia and the sublime are related to it, and are even overlapping at times. However, they also do not capture it. The presentness of space is also subtly different, for the experience in these cases is taken to be out of lived time. After investigating this phenomenon, it is my understanding that its essence is the disclosure of the space contained within a region. Thus, I would like to put forward the neologism topoaletheia: from the Greek $\tau$ ó $\pi$ os, space as contained within limits, i.e. region or place; and $\dot{\alpha} \lambda \eta \dot{\eta} \theta \varepsilon ı \alpha$, discloure, or truth. I speak, however, of a different kind of understanding of truth than as correspondence between a proposition and its object. Aletheia is composed of the privative prefix $a$ - (un- or dis-) and the root lethe (hiddenness, concealment, closure). It thus refers to the truth that first appears when something is revealed, whatever proposition we may use afterwards to refer to it - in short, it is the truth of bringing things out of concealment (see Heidegger, 1959). To disclose something is to momentarily rescue it from its prior unavailability and to witness its presencing. Similarly to light, that presents itself by allowing us to see other objects, Being presents itself to us in making all things seem present. In topoaletheia, Being presents itself to us making the space contained within a region emerge.

The neologism topoaletheia presents two sides of the same coin: a) topo-aletheia as the truth of the space contained within a region-i.e., the presencing of a region as it emerges for the human being to experience it. And b) disclosure of Being through the space contained within a

17 There is a body of literature on the uses of wonder in pedagogy: see van Manen $(1986,1991)$, Hove (1999), Hansen (2010, 2012), and Goble (2013). Speaking of wonder, van Manen argues that "rather than see a child's question as something that needs a quick and simple answer, the adult should try to help in his or her natural inclination to live the question" (1986, pp. 40-41). 
region-i.e. region as a means to know Being; as means for a human being to be exposed to the spatial availability of Being that can be disclosed.

I believe that introducing this neologism to name the distinctive type of spatial experience that is the subject of this essay may enrich the discussion about space. Perhaps bearing the concept of topoaletheia in mind may also prove useful when designing built environments, as it points at a kind of fulfilment experienced through our spatial involvement. This possible practical implication, however, should be developed in further research, as it goes beyond the scope of this essay. 


\section{References}

Addison, J. (1712, June 23 $\left.3^{\text {rd }}\right)$. Essay. The Spectator, 412. London.

Adnams, G. (2002). The experience of singing together in Christian worship. Phenomenology Online. Retrieved from http://www.phenomenologyonline.com/sources/textorium/adnams-gordon-theexperience-of-singing-together-in-christian-worship/ (last accessed on May 26 ${ }^{\text {th }}, 2016$ ).

Ashihara, Y. (1983). The aesthetic townscape. Cambridge, MA: The MIT Press.

Bachelard, G. (1958). The poetics of space. Boston, MA: Beacon Press.

Barrie, T. (1996). Sacred place: myth, ritual, and meaning in architecture. Boston, MA: Shambhala.

Benjamin, W. (1968). The work of art in the age of mechanical reproduction. In Benjamin, W. Illuminations: Essays and Reflections. New York: Schocken Books.

Bergson, H. (1913). Time and free will: and essay on the immediate data of consciousness. London: George Allen \& Company.

Bollnow, O. F. (1961). Lived-space. Philosophy Today, 5(1), 31-39.

Bollnow, O. F. (1971). Mensch und Raum. Stuttgart: Kohlhammer.

Bonner, E. T. \& Friedman, H. L. (2011). A conceptual clarification of the experience of awe: an interpretative phenomenological analysis. Humanistic Psychologist, 39(3), 222-235.

Brown, D. (2004). God and enchantment of place: reclaiming human experience. Oxford: Oxford University Press.

Burke, E. (1757/2014). A philosophical enquiry into the origin of our ideas of the sublime and beautiful. Cambridge: Cambridge University Press.

Csikszentmihalyi, M. (1992). Flow: the classic work on how to achieve happiness. London: Rider.

Cullen, G. (1971). The concise townscape. London: The Architectural Press.

Dear, M. (2000). The postmodern urban condition. Oxford: Blackwell.

Eliade, M. (1957). The sacred and the profane: the nature of religion. New York: Houghton Mifflin Harcourt PC.

Elkins, D. N. (2001). Reflections on mystery and awe. Psychotherapy Patient, 11, 163-168.

Elkins, D. N., Hedstrom, L., Hughes, L. L., Leaf, J., \& Saunders, C. (1988). Toward a humanisticphenomenological spirituality. Journal of Humanistic Psychology, 28(4), 5.

Flood, G. (1999). Beyond phenomenology: rethinking the study of religion. London: Cassell.

Freeman, B. C. (1995). The feminine sublime: gender and excess in women's fiction. Berkeley and London: University of California Press.

Fried, M. (1982). Art and objecthood: essays and reviews. Chicago: University of Chicago Press.

Gallagher, W. (1993). The power of place: how our surroundings shape our thoughts, emotions and actions. New York: Poseidon Press. 
Gelder, M. G. (1982). Agoraphobia and space phobia. British Medical Journal 284(6309), 72.

George, V. (2000). The experience of Being as goal of human existence: the Heideggerian approach. Washington D.C.: The Council for Research in Values and Philosophy.

Goble, E. (2013). Sublimity \& the image: a hermeneutic phenomenological exploration. Phenomenology \& Practice 7(1), 82-110.

Hansen, F. (2010). Phenomenology of wonder in higher education. In M. Brinkmann (Ed.), Erziehung. Phänomenologische perspektiven (pp. 161-177). Würzburg: Königshausen \& Neumann.

Hansen, F. (2012). One step further: the dance between poetic dwelling and Socratic wonder in phenomenological research. Indo-Pacific Journal of Phenomenology, 12(2), 1-20.

Harper, R. (1991). On presence: variations and reflections. Philadelphia: Trinity Press International.

Harries, K. (1990). The broken frame: three lectures. Washington, D.C.: CUA Press.

Harries, K. (2000). The ethical function of architecture. Cambridge, MA: The MIT Press.

Harries, K. (2001). Infinity and perspective. Cambridge, MA: The MIT Press.

Heidegger, M. (1927/1962). Being and Time. Oxford: Blackwell.

Heidegger, M. (1959). Introduction to Metaphysics. New Haven: Yale University Press.

Heidegger, M. (1971). Building, dwelling, thinking. New York: Harper and Row.

Heidegger, M. (2004). What is called thinking? New York: Perennial.

Hick, J. 1989, An interpretation of religion: human responses to the transcendent. Basingstoke: Macmillan.

Hofmannsthal, H. (2008). The whole difference: selected writings of Hugo von Hofmannsthal. J.D. McClatchy (ed.). Princeton, NJ: Princeton University Press.

Hove, P. (1996). The face of wonder. Journal of Curriculum Studies 28(4), 437-462.

Hove, P. (1999). Wonder and the agencies of retreat. (Doctoral dissertation). University of Alberta, Canada.

Jaeger, S. (2010). Magnificence and the sublime in medieval aesthetics: art, architecture, literature, music. London: Palgrave Macmillan.

Jager, B. (1971). Horizontality and verticality: a phenomenological exploration into lived space. In A. Giorgi (ed.), Duquesne Studies in Phenomenological Psychology, Volume IV, (pp. 212-235).

Jameson, F. (1991). Postmodernism, or the cultural logic of late capitalism. London: Verso.

Jaspers, K. (1971). Philosophy of existence. Philadelphia: University of Pennsylvania Press.

Jones, L. (2000). The hermeneutics of sacred architecture: experience, interpretation, comparison. Volume II: Hermeneutical calisthenics: a morphology of ritual-architectural priorities. Cambridge, MA: Harvard University Press.

Kant, I. (1790/1987). Critique of judgment. Indianapolis: Hackett Publishing Co. Inc. 
Keene, D. (2003). Yoshimasa and the Silver Pavilion: the creation of the soul of Japan. New York: Columbia University Press.

Kim, M. (2002). Being nostalgic. Phenomenology Online. Retrieved from http:/www.phenomenologyonline.com/sources/textorium/kim-mijung-being-nostalgic/ (last accessed on May 26 $6^{\text {th }}, 2016$ ).

Koren, L. (1994). Wabi-Sabi: for artists, designers, poets and philosophers. Berkeley: Stone Bridge Press.

Lane, B. (2000). Landscapes of the sacred: geography and narrative in American spirituality. Baltimore: John Hopkins University Press.

Lyotard, J. F. (1994). Lessons on the analytic of the sublime. Stanford, CA: Stanford University Press.

Marion, J. L. (2002). Being given. Toward a phenomenology of givenness. Stanford, CA: Stanford University Press.

Newman, B. (1948). The sublime is now. In Tiger's Eye, 1(6), 51-53.

Norberg-Schulz, C. (1979). Genius loci: towards a phenomenology of architecture. New York: Rizzoli.

O'Hear, A. (1984). Experience, explanation and faith: an introduction to the philosophy of religion. London: Routledge \& Kegan Paul.

Otto, R. (1923). The idea of the holy. New York: OUP.

Parsons, H.L. (1969). A philosophy of wonder. Philosophy and Phenomenological Research 30(1), 84-101.

Pickles, J. (1985). Phenomenology, science and geography: spatiality and the human sciences. Cambridge: Cambridge University Press.

Prat-Ferrer, J. J. (2008). Bajo el árbol del paraíso: historia de los estudios sobre el folclore y sus paradigmas. Madrid: CSIC.

Relph, E. (1976). Place and placelessness. London: Pion.

Seamon, D. (1979). Geography of the lifeworld: movement, rest, and encounter. New York: St. Martin's Press.

Seamon, D. (1982). The phenomenological contribution to environmental psychology. Journal of Environmental Psychology, 2, 119-140.

Seamon, D. (1993). Dwelling, seeing, and designing: toward a phenomenological ecology. New York: SUNY Press.

Seamon, D. \& Lundberg, A. (2015). Humanistic geography. In D. Richardson, (Ed.), International encyclopedia of geography: people, the Earth, environment, and technology. New York: Wiley.

Seamon, D. \& Mugerauer, R. (1985). Dwelling, place and environment: towards a phenomenology of person and world. Dordrecht: Martinus Nijhoff.

Smart, N. (1973). The phenomenon of religion. London: Macmillan. 
Spiegelberg, H. (1960). The phenomenological movement: a historical introduction. The Hague: Nijhoff.

Tuan, Y. F. (1974). Topophilia: a study of environmental perception, attitudes and values. New York: Columbia University Press.

Tuan, Y. F. (1975). Place: an experiential perspective. The Geographical Review, 65(2), 151-165.

Tuan, Y. F. (1977). Space and place: the perspective of experience. London: Edward Arnold.

Turner, H. (1979). From temple to meeting House: the phenomenology and theology of places of worship. The Hague: Mouton Publishers.

Van Manen, M. (1986). The tone of teaching. Richmond Hill, ON: Scholastic.

Van Manen, M. (1991). The tact of teaching: The meaning of pedagogical thoughtfulness. London, ON: The Althouse Press.

Verhoeven, C. (1972). The philosophy of wonder: an introduction and incitement to philosophy. London: MacMillan.

Weiskel, T. (1976). The Romantic sublime: studies in the structure and psychology of transcendence. Baltimore \& London: Johns Hopkins University Press.

White, S. (1995). The theology of sacred space. In D. Brown \& A. Loades, (Eds.) The sense of the sacramental: movement and measure in art and music, Place and Time, (pp. 31-43) London: SPCK.

$\mathrm{Wu}, \mathrm{Z}$. (2002). The lived experience of being a foreigner. Phenomenology Online. Retrieved from http://www.phenomenologyonline.com/sources/textorium/wu-zhou-the-livedexperience-of-being-a-foreigner/ (accessed May 26 ${ }^{\text {th }}, 2016$ ). 